\title{
A REPÜLŐTÉR ÉS VÁROSTÉRSÉG KÖZLEKEDÉSI KAPCSOLATA INNOVATÍV SZOLGÁLTATÁSOK IGÉNYBEVÉTELÉNEK KONTEXTUSÁBAN A BUDAPEST LISZT FERENC NEMZETKÖZI REPÜLÖTÉR PÉLDÁJÁN KERESZTÜL
}

\author{
${ }^{1}$ Tóth Dávid - ${ }^{2}$ Marossy Márton Ottó - ${ }^{3}$ Miskolczi Márk \\ ${ }^{1}$ Pécsi Tudományegyetem Közgazdaságtudományi Kar, david.toth@munich-airport.de \\ ${ }^{2}$ Budapesti Corvinus Egyetem, marton.marossy@stud.uni-corvinus.hu \\ ${ }^{3}$ Budapesti Corvinus Egyetem, mark.miskolczi@uni-corvinus.hu
}

DOI: 10.15170/TVT.2021.06.02.03

\begin{abstract}
Absztrakt
A tanulmány arra tesz kísérletet, hogy Magyarország elsőszámú nemzetközi repülőterét annak földi megközelíthetőségének kontextusába helyezze, kategorizálja és elemezze megközelíthetőségi kapcsolatait. A szerzők olyan tényezőket vizsgálnak, amelyek segítségével a keresletet és az arra vonatkozó folyamatosan változó igényeket mérni, illetve bizonyítani lehet. A kutatás gerincét a repülőtér és a városközpont között elérhető közlekedési eszközök jellemzőinek a vizsgálata és a közlekedési módokhoz kapcsolódó, különösen az $\mathrm{Y}$ és a $\mathrm{Z}$ generáció fogyasztói véleményén alapuló általános igények felmérése szolgáltatja. A szerzők netnográfiás kutatás keretein belül végzett vizsgálata, illetve a kvantitatív megkérdezésük innovatív fejlesztések és szolgáltatások iránti igények feltárását tették lehetővé. A kutatás eredményei Budapest és annak központi repülötere közötti közlekedés esetében a hagyományos közlekedési formák dominanciáját, a fogyasztók innovatív közlekedési megoldásokra való nyitottságát bizonyították.
\end{abstract}

Kulcsszavak: közlekedés, légi közlekedés, repülötér, megközelithetöség, vonzáskörzet

\begin{abstract}
The study attempts to place Hungary's number one international airport in the context of its ground accessibility, categorize and analyze its accessibility relationships. The authors examine factors that can be used to measure and demonstrate demand and its ever-changing needs. The backbone of the research is provided by the examination of the characteristics of the means of transport available between the airport and the city center and the assessment of the general needs related to the modes of transport, in particular based on consumer opinion of the $\mathrm{Y}$ and $\mathrm{Z}$ generations. The authors' research through netnographic research and quantitative interviews made it possible to explore the need for innovative developments and services. The results of the research proved the dominance of traditional forms of transport and the openness of consumers to innovative transport solutions in the case of transport between Budapest and its central airport.
\end{abstract}

Keywords: traffic, air traffic, airport, accessibility, agglomeration 


\section{Bevezetés}

Mai felgyorsult világunkban az utazás szinte alapvető szükségletté vált. Általános igényként írható le, hogy nemzetközi szinten a minél szélesebb körü utazói igények kielégítéséhez az egyre nagyobb forgalmat lebonyolító közlekedési rendszer folyamatos fejlődése szükséges. Ez alól hazánk sem kivétel. Ugyanez vonatkozik a közlekedési rendszer egyik legfontosabb XXI. századi komponensére, a légi közlekedésre és az azt kiszolgáló szárazföldi közlekedési rendszerre is. A szerzők a jelen kutatásban a közlekedési rendszer egy olyan részletével foglalkoznak, amelyben a turistaérkezések és azok kiszolgálásának kontextusában egyértelműen prezentálható az érkezések számával explicit módon növekvő utazások kiszolgálására igénybe vett közlekedési eszközök terheltsége, azok hatékony alkalmazásának szükségessége, esetleges kedveltsége, továbbá a rugalmassága iránti megnövekedett igény.

A korábbi kutatások (MARK KIEFER CONSULTING 2019, MEYER et al. 2019, PEEREBOOM 2019) nemzetközi kitekintésben arra hívták fel a figyelmet, hogy egyes országokban a repülőterek szárazföldi megközelíthetősége tekintetében drámai gyorsasággal szorul vissza a hagyományos közlekedési szolgáltatások igénybevétele. Magyarországon ez a kutatási terület innovatív szolgáltatások kontextusában még egy kevésbé kutatott területnek tekinthető, így a feltáró kutatásunk hiánypótló kutatás is. A kutatás arra keresi a választ, hogy Budapesten a hagyományos közlekedési szolgáltatások visszaszorulása, piaci részesedésük csökkenése jelenleg mennyire tekinthető valós jelenségnek. A tanulmány fő célja a Budapest Liszt Ferenc Nemzetközi Repülőtér földi megközelíthetőségének feltérképezése, a város és maga a repülőtér közlekedési kapcsolatának elemzése igazodva a modern piaci igényekhez. A szerzők törekednek a repülötér megközelíthetőségével kapcsolatos fogyasztói attitüdök bemutatására, ennek érdekében pedig netnográfiás kutatás segítségül hívásával és az abból származó eredmények feldolgozásával fogyasztók közlekedési eszközök használatára való nyitottságát vizsgálják. A szerzők arra keresik a választ, hogy a közlekedési eszközök jellemzőinek meghatározott sillabusz általi értékelési szempontjai - az idő, a költség, a kényelem és a rugalmasság - mekkora szerepet játszanak az utazáshoz használt közlekedési eszközök kiválasztásában, illetve a befolyásoló tényezők között felállítható-e egyfajta prioritási sorrend. Ennek részeként az innovatív megoldásokra vonatkozó alapvető fogyasztói nyitottság, ezzel párhuzamosan a jelenlegi szolgáltatások fejlesztéséből adódó keresletnövekedés lehetőségei kerülnek górcső alá.

\section{A kutatás elméleti háttere}

\subsection{A turizmus alapja a közlekedés}

A közlekedési piachoz kapcsolódó tényezők vizsgálata során nélkülözhetetlen olyan alapvető definíciók tisztázása, mint a turizmus, illetve a közlekedés. A Turizmus Világszervezete (UNWTO) és az Interparlamentáris Unió 1989-ben, Hágában elfogadott turizmus definíciójának értelmében a turizmust, mint „,...a személyek lakó és munkahelyen kívül szabad helyváltoztatását, valamint az azokból eredő szükségletek kielégítésére létrehozott szolgáltatásokat" írja le (PUCZKÓ - RÁTZ 1998:18). Ezzel olyan megfogalmazás kerül előtérbe, amelynek köszönhetően az egyén szerepe központi kérdéssé válik. Ehhez kapcsolódik a helyváltoztatás, a helyváltoztatáshoz használt tér, az ott átélt élmény, valamint annak objektív és szubjektív vetülete. Michalkó Gábor ezt az elméleti fogalmat tette teljessé, amikor a turizmus egy olyan alternatív definícióját ismertette meg a széles nyilvánossággal, amely értemében az egyén élményszerzéssel párosuló környezetváltozásának, továbbá szolgáltatások igénybevételének kontextusa lett a hangsúlyos elem (MICHALKÓ 2001, MICHALKÓ 2008, MICHALKÓ et al. 2009). 
A turizmus központi elemeként a közlekedés, a könnyebb helyváltoztatás eszköze definiálható, amely a távolságból adódó korlátozó tényezők leküzdésével jó néhány ország turizmusban rejlö potenciáljának hasznosíthatóságát, területeinek versenyképességét, azok ebből fakadó gyors anyagi gazdagodásuk eszközét is jelenti (ERDÖSI 1999, ERDÖSI 2002). A turisztikai tér a helyváltoztatás kontextusában három elemet foglal magába. Az utazást generáló területet, amely az utazás kiinduló- és befejező helye. A fogadóterületet, amely az utazás célpontja. Továbbá az átutazás területét, amelyen keresztül az egyének utaznak, és amely összeköti a korábban említett küldö- és fogadóterületet (LEIPER 1979). A távolság és az idő, valamint a költség kapcsolata kerül a középpontba (LEIPER 1979, MICHALKÓ 2008, MICHALKÓ et al. 2009), így az általunk bemutatott kutatás ez által tudomány-rendszertani besorolás alapján nem a turizmus definíciójára szükülő, a helyváltoztatás általános vizsgálatára törekszik, hanem átfogó közlekedéssel foglalkozó kutatásokra alapozva (KASARDA 2000, KASARDA 2008, BOTHNER et al. 2013, BOHL et al. 2017, JÁSZBERÉNYI - MUNKÁCSY 2018, BAKONYI et al. 2019) kihasználva a korábbi kutatások által nyitva hagyott ürt, Magyarország központi repülőterének földi megközelítését biztosító közlekedési eszközök, azok kedveltségére, élményszerzést biztosítani tudó mivoltára és szolgáltatási minőségének vizsgálatára koncentrál.

\section{A kutatás módszertana}

\subsection{A netnográfiás kutatás}

A turizmus szektor az elmúlt évek dinamikus fejlődéséből adódóan joggal tekinthető a világ egyik legjelentősebb gazdasági hajtómotorjának. A világ turistaérkezéseinek száma 2018-ban elérte az 1,4 milliárd föt, ami világszinten 5\%-os növekedést jelent az előző év adataihoz képest (World Tourism Organization 2019), és bár a nemzetközi turistaérkezések számának a növekedése 2019ben a korábbi évekhez viszonyítva lassulást mutat (World Tourim Organization 2021), a turizmus egyre növekvő mértékű jelentőségéből adódóan a közlekedés fogalma is egyértelmü létjogosultságot nyer a téma szempontjából meghatározó fogalmak között. A kutatásunkban a közlekedés, amely során tömegszerü helyváltoztatás biztosításával hálózatokba szervezett infrastruktúrára és müszaki berendezések felhasználására kerül sor (JÁSZBERÉNYI MUNKÁCSY 2018) egy olyan részletével foglalkozunk, amely során az 1. ábra által szemléltetett fogyasztói kereslet a távolság kontextusában az utazási tér, az idő, a költség, a kényelem és a rugalmasság harmonizációjára alapozva kerül meghatározásra.

\section{1. ábra: A fogyasztói kereslet}

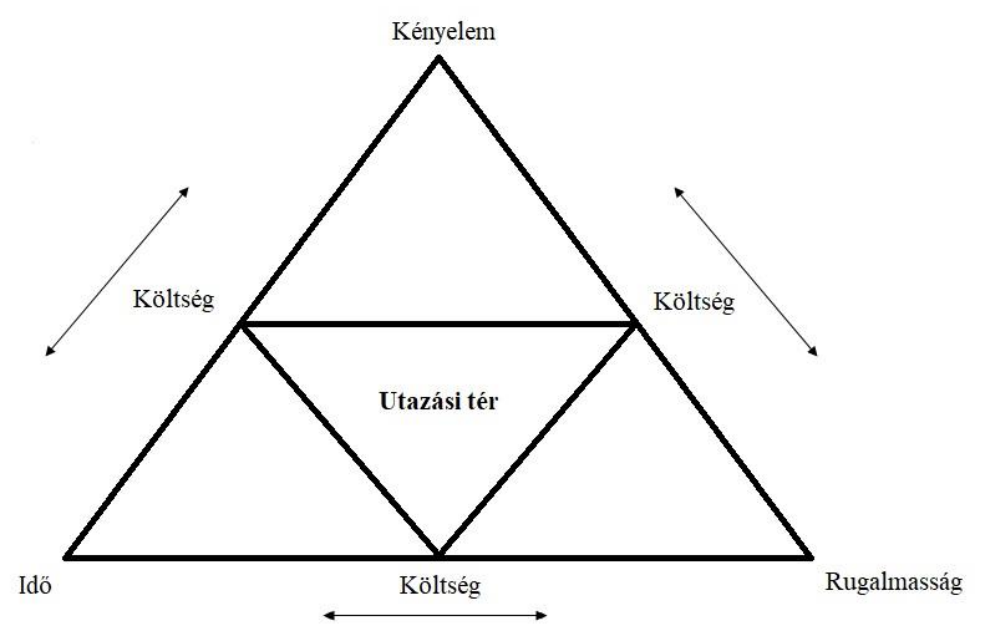

Forrás: Saját szerkesztés 
A tanulmány fogyasztói véleményekre alapozva következtetések levonását tüzte ki célul és arra a kérdésre keresi a választ, hogy a hagyományos közlekedési szolgáltatások visszaszorulása, azok piaci részesedésének csökkenése a korábbi nemzetközi kutatásokból kiindulva (MEYER et al. 2019, PEEREBOOM 2019) mennyire tekinthetők jelenleg Budapesten is valós jelenségnek.

A közlekedésben résztvevők preferenciáinak felmérése során egyes korábbi kutatások (BÉIRÃÖ CABRAL 2007, LE-KLÄHN et al. 2014, GEBHARDT et al. 2016, İMRÉ - ÇÉLÉBI 2017) által többféle vizsgálati módszer alkalmazása is látható. Általánosan megállapítható, hogy ők a közlekedési eszközök kiválasztásának vizsgálatában az ár, a kényelem, az utazási idő, továbbá a tisztaság és az utazási élmény fogalmát tekintették elsődlegesnek. Egyfajta közlekedési igény és tevékenység szimulációs modell alkalmazásával a közlekedési eszközök különböző helyzetekben történő általános kihasználtságának vizsgálata (GEBHARDT et al. 2016), továbbá prioritási sorrendek felállítása faktoranalízis, vagy többszörös választásos modellek alapján kapott központi szerepet. A közlekedési eszközök preferálását befolyásoló tényezök tekintetében az említett kutatásokra alapozva ez által nem is lehet általánosan egy közös preferencia-sorrendet felállítani. Az árak és a kényelem szerepének elsődlegessége ugyanúgy megfigyelhető az egyes kutatások eredményei alapján (BÉIRÃÖ - CABRAL 2007, İMRÉ - ÇÉLÉBI 2017), mint az utazás közbeni cselekvési szabadság, a szabad időtöltés fontossága (LE-KLÄHN et al. 2014), illetve a megbízhatóság tényezője (REDMAN et al. 2013).

Éppen ebből adódóan, ezen ellenmondásokból kiindulva egy pontosabb kutatási eredmény elérése érdekében mi a primer kutatást egy netnográfiás kutatással alapozzuk meg. Tehát a netnográfia általános modelljének (2. ábra) alkalmazásával ezen kutatás által megállapított eredményeket tekintjük kiindulópontnak, és az itt elért eredményeket vetítjük a kérdőíves megkérdezésünkre. A meghatározott lépéseket alkalmazva a kulturális entrée meghatározása, az online kommunikációs platformok kiválasztása, valamint a kutatói részvétel típusának a megválasztása tartoznak az elödleges lépések közé. Ezt követően történik meg maga az adatgyüjtés, amelyet az eredmények értelmezése és az eredmények hiteles bemutatása követ. Az etikus kutatás az egyes kutatási alapelvek betartására irányul. A netnográfia végül visszacsatolással zárul, így biztosítva azt, hogy a résztvevőknek lehetőségük legyen beleszólni a kutatási eredmények értelmezésébe. Azonban tekintettel arra, hogy nem a netnográfia a hangsúlyosabb kutatása a tanulmánynak, az utolsó lépés megvalósítására nem kerül sor. A netnográfia ez esetben ugyanis az ötödik lépés lefolytatása nélkül is eléri a célját.

\section{2. ábra: A netnográfia lépései}

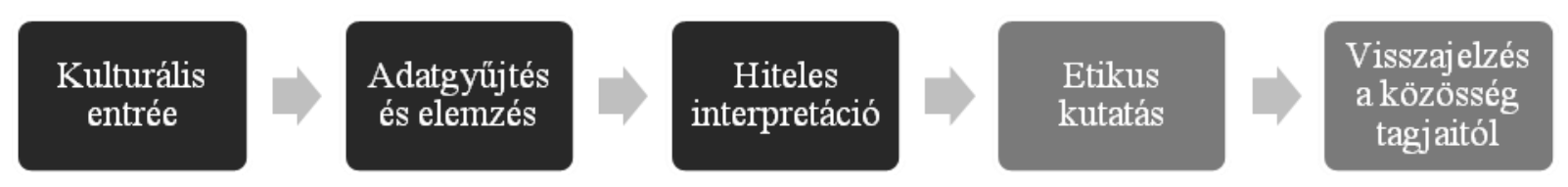

Forrás: HORVÁTH - MITEV (2015) alapján saját szerkesztés. 
A fent említett szempontokat figyelembe véve első lépésként a repülőtéri közlekedésben szerepet játszó releváns információk körének meghatározása, a felhasználók attitüdjeinek, tapasztalatainak, a megjelenő problémáinak felderítése volt a cél. A kulturális entrée részeként további meghatározásra kerültek azok a felületek, melyeken keresztül a vélemények elérhetővé válnak számunkra. Fontos azonban megemlíteni, hogy a részletes és pontos adatok elérésének lehetőségei az ilyen típusú kutatásoknál erősen korlátozottak, mivel a téma kapcsán sokszor rendkívül kevés adatforrás áll rendelkezésre és ezek egy része akár évekkel korábbi véleményeken is alapulhatnak. A kutatásunkban egy pontosabb és a jelenlegi állapotokat jobban tükröző kép elérése érdekében az utazók véleményének feltárásánál alapvető kritériumként fogalmaztuk meg a két évnél korábbi vélemények figyelmen kívül hagyását. A hiteles interpretációnak eleget téve a kutatási eredményeket és tapasztalatokat táblázatokba rendszereztük. A netnográfiás kutatás során életkortól függetlenül került sor releváns információk, vélemények és problémák feltárására, mivel egy ilyen jellegü kutatás keretein belül pontosan nem feltétlenül lehetett meghatározni a véleményét megfogalmazó egyének akár legszükebb értelemben vett személyes, demográfiai adatait sem.

\subsection{A primer kutatás}

A tanulmány az általunk bemutatott alapozó netnográfiás kutatást egy primer kutatással tette teljessé. A primer kutatásban történő részvétel lehetősége - ellentétben a netnográfiás adatgyüjtéssel - bár mindenki számára elérhető volt, hasonlóan korábbi kutatások fókuszcsoportos megkérdezéseihez (PRENSKY 2001, TÖRÖCSIK 2011), az egyszerü összehasonlíthatóság érdekében jelen kutatás elsősorban a már posztmodern világ szülötteinek tekinthető Y generáció és a világ első globális nemzedékének tekinthető $Z$ generáció igényeire fókuszált, tehát a kérdőíves megkérdezésünk generáció-orientált felmérésnek tekinthető. Igazodva a korábbi kutatásokhoz (TÖRÖCSIK 2009, MISKOLCZI et al. 2021) az 1980 és 1995 között születetteket az Y generációba, az 1996 és a 2010 között születetteket a Z generációba soroltuk. A feltáró kutatás kvantitatív részében a megkérdezést tudatosan olyan csatornákon keresztül juttattuk el a potenciális kitöltők számára, amelyekkel föleg a fiatalabb generáció tagjait lehetett elérni. A kutatásban való részvétel minimálisan támasztott feltétele az volt, hogy a kitöltőknek az elmúlt három évben legalább egyszer kellett Budapest Liszt Ferenc Nemzetközi Repülöterén keresztül utazniuk, valamint az, hogy a budapesti közlekedési rendszert legalább minimálisan ismerik így érve el azt, hogy a megkérdezés rávilágítson a repülőtérre való eljutás, illetve annak elhagyásának fogyasztói szokásaira, továbbá a közlekedési eszközök kiválasztásának elsődleges szempontjaira.

\section{A kutatás eredményei}

\subsection{A netnográfiás kutatás}

Az irodalmi áttekintésünk megállapításai alapján netnográfiás kutatáson alapuló adatgyüjtésünket a kvantitatív kutatásunkat előkészítő alapkutatásnak tekintettük, amely során online elérhető, objektív alapokon szubjektív élményekre alapozó értékeléseket dolgoztunk fel. Az adatfelvételt 2020. július 1. és 2020. augusztus 31. között végeztük. A jelen kutatásban elsődleges célunk a jelenlegi piaci helyzet fogyasztói szemszögéböl történő megismerése olyan online média platformokon, ahová a vélemények elsősorban felhasználói úton kerülnek megosztásra. A vizsgálatunkban a magyar és az angol nyelven megjelent hozzászólások kerültek vizsgálat alá, továbbá feltétel volt, hogy a hozzászólásoknak az elmúlt öt évben kellett megjelenniük. Az adatgyüjtés folyamán mindvégig tiszteletben tartottuk a résztvevők anonimitását, így a demográfiai adatok mellőzésével Budapest és annak nemzetközi repülőterének közlekedési kapcsolatával összefüggő fogyasztói attitüdök és szubjektív vélemények vizsgálata jelentette elsősorban a kutatás e fázisát. 
Három online közösségi platform - Facebook, Google és a Play Áruház - felületén történt meg az egyes szolgáltatások kedveltségének kiértékelése reakciók és hozzászólások alapján. Általánosan már a kutatás kezdeti státuszában abból az aspektusból indultunk ki, hogy a mai társadalom tagjai az okostelefonok, a tabletek és a számítógépek világában - szélsőséges esetekben a függés jeleit mutatva - egyszerủen túl sok időt töltenek a közösségi média oldalainak használatával, az egyes szolgáltatók pedig igyekeznek kihasználni a szolgáltatásaik megismertetésével az ebben rejlő potenciált.

Az adott szolgáltatók célzottan jelennek meg ezeken a felületeken, ahol követve a megváltozott fogyasztói szokásokat próbálnak a fogyasztók mindennapjainak valamilyen formában a részeseivé válni. Általánosan megállapítható, hogy a szolgáltatókkal kapcsolatos közvetlen visszajelzés lehetőségével a felhasználók valóban szeretnek élni, sokszor a kisebb fejlesztések hírére is azonnal pozitívan vagy épp negatívan reagáló felhasználók mellett az általános kérdésekben kiteljesedő, sokszor az átélt élményeikre összpontosító, illetve a szolgáltatásokat feltételezhetően kevésbé használó mégis véleményt formálók egyaránt képviseltetik magukat. Az általunk vizsgált, a közlekedési mobilitás területén érintett szolgáltatók jelenleg ugyan még nem mindegyike elérhető az összes online közösségi média felületen, viszont a kutatásunk jelenlegi szakaszában a számunkra hasznos adatok feltérképezésének érdekében a rendelkezésre álló adatok ettől függetlenül elégségesnek bizonyultak. A szolgáltatók vizsgálata négy csoportra lebontva ment végbe (1. táblázat). A kutatás során valamennyi, Budapesten múködő autómegosztó szolgáltatóról GreenGo, Mol Limo, ShareNow - az online közösségi platformok felületein alkotott felhasználói vélemények alapján azok kedveltségének kiértékelése reakciók és hozzászólások alapján történt meg. A transzferszolgáltatás területén a miniBUD került górcső alá. A repülőtér hivatalos taxiszolgáltatóját (Fötaxi), illetve a budapesti tömegközlekedés által biztosított lehetőségeket is rendszereztük Budapest központi repülőterének kontextusában a rendelkezésre álló információk alapján. Az egyes szolgáltatók esetében az egyszeri utazás minimális árának a meghatározásánál a szolgáltatók honlapján 2020. augusztus 8-án elérhető árakat vettük alapul. Ahol volt rá lehetőségünk, ott az egyes szolgáltatók honlapjain elérhető díjkalkulátorokat alkalmaztuk, az utazás minimális időtartamának a meghatározásánál pedig a Google Maps internetes térképszolgáltatás volt a segítségünkre.

A rendelkezésre álló adataink feldolgozásából kiderült, hogy jelenleg a Budapest Liszt Ferenc Nemzetközi Repülötér és a városközpont kapcsolatában a GreenGo mint Magyarország autómegosztási piacára elsőként belépő szolgáltató tekinthető a leginkább ismert, legtöbb hozzászólást generáló jármümegosztónak az online közösségi média felületén aktívan résztvevő felhasználók körében. A miniBUD általánosságban kedvezőtlenebb értékeléssel rendelkezik valamennyi vizsgált szolgáltatással való összevetés alapján. A taxiszolgáltatással kapcsolatos visszajelzések száma az átlagosnál jelentősen nagyobb a többi szolgáltatóhoz viszonyítva, miközben a repülötér hivatalos taxiszolgáltatójával (Fötaxi) kapcsolatos utazói attitüdök felmérésében az is sokat segített, hogy a Google értékelésében külön értékelni lehet a szolgáltató által nyújtott szolgáltatások minőségét kifejezetten a repülőtér és a városközpont közötti viszonylatban is (1. táblázat). 
1. táblázat: A szolgáltatók kedveltsége és alapvető jellemzőik

\begin{tabular}{|c|c|c|c|c|}
\hline Szolgáltatás & Szolgáltató & $\begin{array}{l}\text { Facebook } \\
\text { (hozzászólások }\end{array}$ & $\begin{array}{l}\text { Google } \\
\text { (hozzászólások }\end{array}$ & $\begin{array}{l}\text { Play Áruház } \\
\text { (hozzászólások }\end{array}$ \\
\hline \multirow{3}{*}{ Autómegosztás } & GreenGo & 251 & 102 & 59 \\
\hline & Mol Limo & 181 & 58 & 88 \\
\hline & $\begin{array}{l}\text { ShareNow } \\
\text { Hungary }\end{array}$ & 19 & $x$ & - \\
\hline $\begin{array}{l}\text { Repülötéri } \\
\text { transzferszolgáltatás }\end{array}$ & $\operatorname{miniBUD}$ & 18 & 598 & $x$ \\
\hline Taxi & Fötaxi & 302 & 196 & 97 \\
\hline $\begin{array}{l}\text { Busz 100E } \\
\text { Busz 200E }\end{array}$ & $B K K$ & $x$ & $x$ & $x$ \\
\hline Szolgáltatás & Szolgáltató & $\begin{array}{l}\text { Kedvelök száma } \\
\text { (Facebook) }\end{array}$ & $\begin{array}{l}\text { Értékelés } \\
\text { (Google) }\end{array}$ & $\begin{array}{l}\text { Értékelés } \\
\text { (Play Áruház) }\end{array}$ \\
\hline \multirow{3}{*}{ Autómegosztás } & GreenGo & 17192 & 4,4 & 3,7 \\
\hline & Mol Limo & 10476 & 4,0 & 3,8 \\
\hline & $\begin{array}{l}\text { ShareNow } \\
\text { Hungary }\end{array}$ & 3315 & - & - \\
\hline $\begin{array}{l}\text { Repülötéri } \\
\text { transzferszolgáltatás }\end{array}$ & miniBUD & 3180 & 3,5 & 2,7 \\
\hline Taxi & Fötaxi & 20205 & 4,6 & 4,4 \\
\hline Szolgáltatás & $\begin{array}{l}\text { Egyszeri } \\
\text { utazás }\end{array}$ & $\begin{array}{l}\text { Utazás } \\
\text { minimális }\end{array}$ & \multicolumn{2}{|c|}{ Végpont a repülőtérröl } \\
\hline Autómegosztás & $3865 \mathrm{Ft} / u ́ t$ & 25 & \multicolumn{2}{|c|}{ Budapest Deák Ferenc tér } \\
\hline Magánautó & - & 25 & \multicolumn{2}{|c|}{ Budapest Deák Ferenc tér } \\
\hline Busz 200E & $350 \mathrm{Ft} / \mathrm{fo}$ & 25 & \multicolumn{2}{|c|}{ Budapest Kőbánya-Kispest } \\
\hline Busz 100E & $900 \mathrm{Ft} / \mathrm{fo}$ & 30 & \multicolumn{2}{|c|}{ Budapest Deák Ferenc tér } \\
\hline Taxi & $7283 \mathrm{Ft} / u ́ t$ & $\begin{array}{l}25+\text { várakozási } \\
\text { idö́ }\end{array}$ & \multicolumn{2}{|c|}{ Budapest Deák Ferenc tér } \\
\hline Vasút + Busz 200E & $720 \mathrm{Ft} / \mathrm{fo}$ & $\begin{array}{l}25+15 \\
\text { átszállási idö }\end{array}+$ & \multicolumn{2}{|c|}{ Budapest Nyugati pályaudvar } \\
\hline $\begin{array}{l}\text { Repülötéri } \\
\text { transzferszolgáltatás }\end{array}$ & $1900 \mathrm{Ft} / \mathrm{fo}^{\prime \prime}$ & $\begin{array}{l}30+\text { várakozási } \\
\text { idón }\end{array}$ & \multicolumn{2}{|c|}{ Budapest Deák Ferenc tér } \\
\hline
\end{tabular}

Forrás: Saját szerkesztés. 
Összességében megállapítható, hogy az általunk vizsgált online közösségi felületeken a hozzászólások és a kedvelések kiértékelése, egyben a kérdőíves megkérdezésünket megalapozó kutatásnak tekintett netnográfiás adatgyüjtésünk a legkedveltebb közlekedési eszköznek a taxit mutatják a Budapest Liszt Ferenc Nemzetközi Repülötér és a városközpont közötti viszonylatban annak ellenére, hogy egyes korábbi kutatásokból kiindulva (MARK KIEFER CONSULTING 2019, MEYER et al. 2019, PEEREBOOM 2019) e szolgáltatás visszaszorulását, piaci részesedésének csökkenését feltételeztük. A taxiszolgáltatások visszaszorulásának a folyamatát így a kutatásunk bár általánosan nem zárja ki, ugyanakkor jól látszik, hogy jelenleg a megbízhatóság magas foka miatt egészen biztosan stabil piaci pozícióval rendelkezik Budapesten még annak ellenére is, hogy ez a közlekedési forma tekinthető a Budapesten elérhető szolgáltatások közül egy före vetítve az egyik legdrágább közlekedési szolgáltatásnak.

\subsection{A kvantitatív kutatás eredményei}

A netnográfiás kutatásunk eredményei alapján kérdőívet készítettünk, amelyet kvantitatívan elemeztünk. Az adatfelvételt 2020. szeptember 27. és 2020. október 13. között végeztük a Google Forms online szoftver segítségével. Elsősorban az Y és a $\mathrm{Z}$ generációs alanyok véleményét terveztük feltárni, de az adatfelvételből az egyéb korcsoportokba tartozó válaszadókat sem zártuk ki. A megkérdezésünk technikája nem engedte meg a kérdések kihagyását, így ebből adódóan teljesen kitöltött, jól feldolgozható kérdőíveket kaptunk. A kérdőív adatait a Microsoft Excel program segítségével elemeztük.

A 3. ábra által szemléltetett kutatási eredmények az összesen 140 értékelhető kitöltés alapján a 1624 éves korosztály nagyon jelentős felülreprezentáltságát mutatják (67,1\%). Az idősebb korosztály (55 év felettiek) ugyan nem tartozott a célcsoportunkba, csekély mértékben $(2,1 \%)$ azért ettől függetlenül ök is képviseltetik magukat. A minta 22,9\%-ban férfi és 77,1\%-ban női kitöltőkből állt össze. A kitöltők 63,6\%-a fóvárosi lakos, 13,6\%-a megyei jogú városban, 16,4\%-a egyéb városban, míg 6,4\%-a pedig községekben, falvakban lakik.

\section{3. ábra: A kvantitatív kutatásban résztvevők megoszlása}
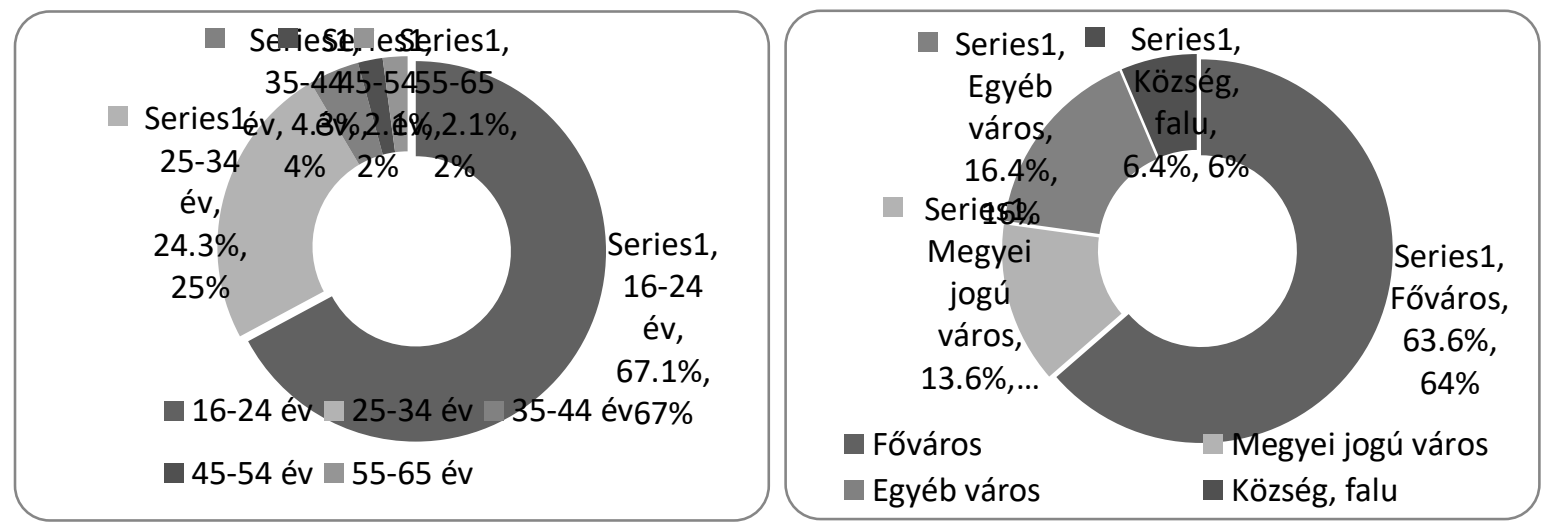

Forrás: Saját szerkesztés.

A végzettség tekintetében két nagyobb csoportról beszélhetünk. Egyrészt a jelenleg is felsőfokú tanulmányaikat folytatók aránya 58,6\%, míg a diplomás, tanulmányaikat már befejezőké 37,9\%. A kitöltők 37,9\%-a az elmúlt években állításuk szerint háromnál is több alkalommal repültek Budapest Liszt Ferenc Nemzetközi Repülőterén keresztül, ők az elvártnál nagyobb mértékben, tehát bőven rendelkeznek olyan tapasztalatokkal, amelyek a kutatás szempontjából relevánsak. Bár a megkérdezés egyik feltétele volt a repülötér használatából következő tapasztalatok megléte, csekély számban olyan kitöltések is érkeztek, ahol a válaszadók egyáltalán nem repültek még 
(10,0\%). Bár a kutatás szempontjából az ő véleményük a legtöbb esetben ugyan nem tekinthető relevánsnak, a kérdőívezés egyes részeiben azonban az ő véleményüket is fel tudtuk használni, különösen ott, ahol az innováció iránti igényt, a repülőtér és a városközpont közötti közlekedésre vonatkozó fejlesztési javaslatokat teszteltük.

Az általunk vizsgált közlekedési módok közül már a kutatás kezdetén látható volt, hogy a kitöltők legalább fele várhatóan több közlekedési módot fog megjelölni és konkrét szubjektív véleménnyel fog rendelkezni Budapest közlekedéséröl. A kérdöívet kitöltőknek saját véleményük és átélt élményeik alapján az utazásaikat az utazási idő, a költség, a kényelem és a rugalmasság befolyásoló ereje szerint kellett értékelniük, továbbá 5 fokozatú Likert-skálán kellett minősíteniük, hogy mennyire tartják Budapesten bonyolultnak a repülötéri közlekedést, illetve mennyire tartják megfelelőnek a jelenleg elérhető szolgáltatásokat (2. táblázat). A Likert-skálán mért átlagok a repülőtéri utazás bonyolultságát $(1-$ jelentős problémát okoz a repülőtéri közlekedésben az eligazodás, 5 - egyáltalán nem okoz problémát az eligazodás) és a szolgáltatások minőségének értékelését ( 1 - egyáltalán nem tartja megfelelőnek, 5 - nagyon megfelelőnek tartja) rangsoroltuk kiemelt figyelmet szentelve az innovatív közlekedési megoldásokra való nyitottságra. Arra a kérdésekre kerestük még a választ, hogy jelenleg a budapesti repülőtéri közlekedésben a magyar utazók innovációk iránti érdeklődése mennyire sokoldalú, illetve az elérhető innovatív közlekedési szolgáltatásokkal mennyire elégedettek.

\section{2. táblázat: Az egyes tényezők fontossági sorrendje}

\begin{tabular}{|c|c|c|c|c|}
\hline Megnevezés & $\begin{array}{l}\text { Utazási } \\
\text { idö }\end{array}$ & $A ́ r$ & Kényelem & $\begin{array}{l}\text { Rugalmass } \\
\text { ág }\end{array}$ \\
\hline $\begin{array}{l}\text { 1. hely (legfontosabb a } \\
\text { kiválasztásban) }\end{array}$ & $45,4 \%$ & $33,1 \%$ & $19,8 \%$ & $1,7 \%$ \\
\hline 2. hely & $35,3 \%$ & $32,9 \%$ & $21,0 \%$ & $10,8 \%$ \\
\hline 3. hely & $9,6 \%$ & $13,8 \%$ & $34,0 \%$ & $42,6 \%$ \\
\hline $\begin{array}{l}\text { 4. hely (legkevésbé fontos a } \\
\text { kiválasztásban }\end{array}$ & $2,7 \%$ & $4,1 \%$ & $15,1 \%$ & $78,1 \%$ \\
\hline $\begin{array}{l}\text { Mennyire tartja bonyolultnak a } \\
\text { repülőtéri közlekedést? (A Likert- } \\
\text { skálán mért átlagok alapján) }\end{array}$ & 2,87 & & & \\
\hline $\begin{array}{l}\text { Mennyire tartja megfelelönek a } \\
\text { jelenleg elérhetoó „car sharing } \\
\text { szolgáltatásokat”? (A Likert- } \\
\text { skálán mért átlagok alapján) }\end{array}$ & 3,79 & 3,00 & 4,21 & 3,90 \\
\hline
\end{tabular}

Forrás: Saját készítés.

A válaszadók általános értékelése alapján Budapest Liszt Ferenc Nemzetközi Repülőterének megközelíthetősége nem tekinthető bonyolultnak, viszont egy jelentős részük $(27,8 \%)$ a budapesti repülötéri közlekedést mégis bonyolultabbnak tartja más európai nagyvárosokhoz viszonyítva. Bár egyes kutatások (MARK KIEFER CONSULTING 2019, MEYER et al. 2019, PEEREBOOM 2019) arra hívják fel a figyelmet, hogy drámai gyorsasággal szorulnak vissza a hagyományos közlekedési eszközök a vizsgált területen, addig az általunk Budapestre vetített, zömében fiatalok közlekedési szokásait felmérö kutatás azt mutatja, hogy a hagyományos közlekedési eszközök szinte semmit nem veszítettek az elmúlt években a piaci részesedésükből és ma is rendkívül beágyazottnak tekinthetőek Budapest közlekedésében (4. ábra). 
Ez véleményünk szerint több tényezőre is visszavezethető. Demográfiai, szociológiai, gazdasági hatások egyaránt befolyásolják az utazási döntést és az utazó közlekedéséhez használt eszközök kiválasztását, továbbá hazánkban a légi közlekedést kiszolgáló repülöterek és a városközpont közötti közlekedés esetében jelenleg még egyfajta merev piac is jellemzö, ahol érezhetően nincs még jelen az a valódi szabad verseny, mint ami például a MARK KIEFER CONSULTING (2019) kutatásában az USA-val kapcsolatban egyértelmüen látható. Ennek egyik kiváló példája hazánkban az Uber szolgáltatás 2016-ban történt betiltása a taxiszolgáltatók védelme érdekében (BERDE 2018).

\section{4. ábra: A válaszadók közlekedési eszköz használatának megoszlása a repülőtéri utazásaik során}

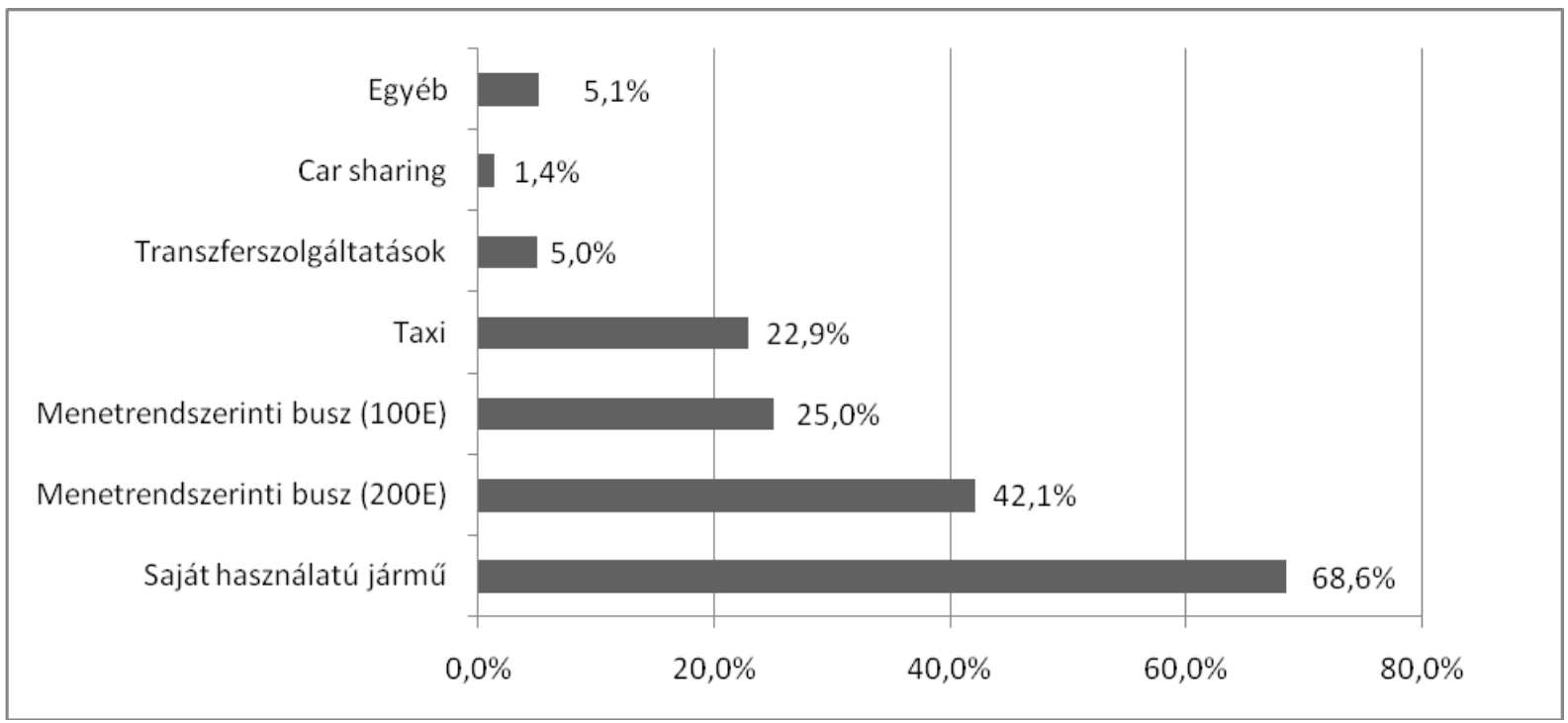

Forrás: Saját szerkesztés.

A közúti tömegközlekedés kapcsán az egyik legfontosabb momentum, hogy egyértelmüen egy heterogén kép látszik a város és a repülőtér között. E közlekedési módok esetében a megfelelő infrastruktúra és alapvetően egy integrált szemléletü menedzselés, egy kézenfekvő utasok felé történő kommunikáció látszik a legfontosabbnak. Mindez beigazolódik a megkérdezésünk utaselégedettséget vizsgáló részében is, ahol a repülötér menetrendszerinti buszokkal történő megközelítése esetén a válaszadók 41,5\%-a elégedetlen, miközben a legkevesebb kritikát az autómegosztáson alapuló szolgáltatások (GreenGo, Mol Limo) és a taxiszolgáltatók kapták (5. ábra). 


\section{5. ábra: A fejlesztésre szoruló közlekedési szolgáltatások a válaszadók véleménye alapján / A hiányosságok oka a válaszadók szerint}
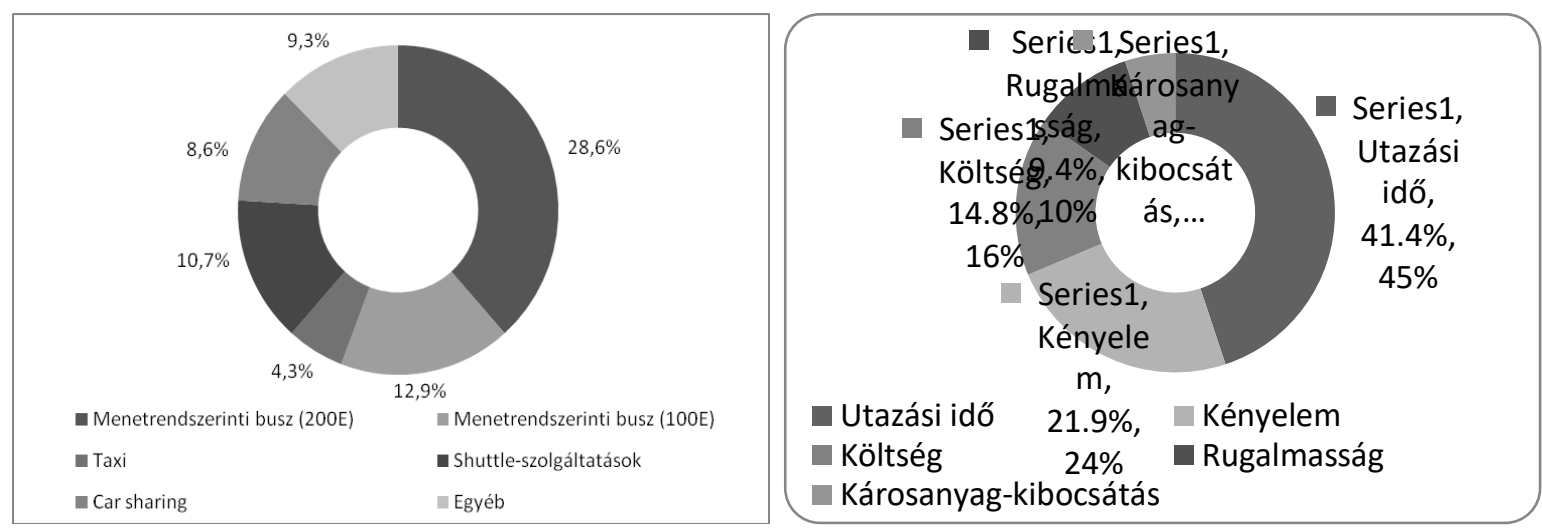

Forrás: Saját szerkesztés.

A kötöttpályás közlekedés iránti igényeket vizsgálva alapvetően jelenik meg a kutatásunkban a költség, a rugalmasság és a kényelem szempontja. A gyorsvasút kapcsán fontos megemlíteni, hogy nem elég egy városközpontot egyszerüen összekapcsolni a repülötérrel, hiszen a repülötér vonzáskörzete ennél lényegesen tágabb terület. Innovatív és piacorientált megközelítéssel szükséges a fogyasztói igényekre választ adni, amelynek fontos része az is, hogy a városközpont és a repülőtér reláció helyett sokszor a várostérség és a repülőtér relációját szükséges elsődlegesnek tekinteni. Ez a Budapest Liszt Ferenc Nemzetközi Repülőtér esetében is egyértelmüen látszik (SOÓKI-TÓTH 2018). Alapvető kérdéssé válik, hogy aki nem a belvárosból indul és nem is oda érkezik, annak hogyan lesz rugalmas, kényelmes és megfizethető a kötöttpályás közlekedés, mivel azon piacokon, ahol a gyorsvasút, mint lehetőség megjelenik, ott komoly változások is megfigyelhetőek a közlekedési eszközök preferálásában (ALBERT - SZÜCS 2018). Erre jó példa Bécs vonatközlekedése, amelyböl akár Budapest is átvehet jó gyakorlatokat. Itt egy nagyon ambivalens megjelenési formával találkozunk. Ha tüzetesebben megvizsgáljuk, akkor az utasok megoszlásán láthatjuk, hogy a belváros és Bécs központi repülőtere között a vasúti szolgáltatásokat elsősorban a külföldiek részesítik előnyben, viszont olyan innovációs kísérletek is láthatóak, amik a helyieket is a vasút használatára ösztönözik. Olyan innovációkat vezettek be az utasok számára, amivel például már a városban is lehetővé vált a légi utasok csomagjainak leadási lehetősége, így az efféle közlekedés már vonzerőként jelent meg a korábban a szolgáltatás iránt amúgy semleges csoportok szemében is. A kérdőívezésünk eredményei is egyértelműen azt tükrözik, hogy az átgondolt innovatív és más szolgáltatásfajtákkal is kombinált szolgáltatásokra egyértelmüen szükség van, a válaszadók 61,4\%-a egy hipotetikus esetben szívesen áttérne a gyorsvasútra Budapest Liszt Ferenc Nemzetközi Repülőterének elérése érdekében is, amennyiben ez a lehetőség ténylegesen rendelkezésre állna számukra, miközben a válaszadók további $27,9 \%$ bár bizonytalan ezzel kapcsolatban, de nem zárkózik el a gondolattól.

A Magyarországon megjelenő első autómegosztó szolgáltatások hirtelen megugró népszerüsége arra enged következtetni, hogy jó eséllyel a korábban említett külső tényezők lehetnek azok, amelyek miatt hazánkban a közlekedési szolgáltatások piaca jelenleg még más képet mutat, mint más országokban. 
Az Uber utazásmegosztó szolgáltatás megjelenése, majd ezt követően a rövid magyarországi müködése alatti gyors piaci térnyerése, vagy a ridesharing szolgáltatások - amelyek szolgáltatás keretein belül egy többnyire szabályozatlan rendszerben az adott jármüvek tulajdonosai általában ismeretlen emberek számára ajánlják fel a jármüveikben lévő üres ülőhelyeket a költségek megosztása céljából (GYÜRÜS et al. 2008) - elterjedése is szintén ezt erősíti.

Tehát mindez azt bizonyítja, hogy jelenleg alapjaiban nem a magyar utazók közlekedésben tapasztalható innovatív megoldások iránti gyenge érdeklödése, vagy hiánya okozza a közlekedési szolgáltatások tágabb értelmezésének hazai elmaradását. Ezt a megállapítást bizonyítják az általunk készített kérdőívezés beérkezett válaszai is, mely szerint a válaszadók 15,7\%-a használt már autómegosztó szolgáltatást annak ellenére, hogy a szolgáltatás csak pár éve érhető el Magyarországon. Bár az utazói nyitottság nem jelent automatikusan tényleges keresletet az autómegosztó szolgáltatások irányába, viszont az bizakodásra okot adó eredménynek tekinthető, hogy a megkérdezettek 53,6\%-a ugyan még soha nem használt autómegosztó szolgáltatást, de a jövőben mindenképp tervezi annak kipróbálását. Így ez egyben azt is jelenti, hogy a jelenlegi aktív felhasználókon túl létezik egy olyan csoport, amelynek tagjaira, mint az autómegosztáson alapuló szolgáltatás későbbi esetleges potenciális felhasználóiként tekinthetünk. Bár az autómegosztás elterjedésének kapcsán külföldi példákat automatikusan nem lehet Magyarországra vetíteni, viszont ettől függetlenül potenciálisan adott a lehetőség arra, hogy hasonlóan a külföldi példákhoz, Magyarországon is egyre nagyobb mértékben szoruljon háttérbe a hagyományos közlekedési eszközök piaci részesedése az innovatívabb szolgáltatások javára.

\subsection{A repülőtéri közlekedési szolgáltatások hiányosságai Budapesten}

A kutatásunkban kísérletet tettünk az utazók választását leginkább befolyásoló tényezők fontossági sorrendjét felmérni, ahol a kapott eredmények alapján felépítettünk egy rangsort a fejlesztésre szoruló közlekedési szolgáltatásokat vizsgálva (5. ábra). A kitöltők szerint leginkább az utazási idő komponensével van a legnagyobb probléma Budapesten a repülőtér és a városközpont között, tehát túl hosszúnak érzékelik azt az időt, ami alatt a repülőteret a városközpontból el lehet érni $(41,4 \%)$. Ezt követi a kényelem gyenge minősége (21,9\%), a megtett útra vetített magas költség $(14,8 \%)$, az alacsony szintủ rugalmasság $(9,4 \%)$, majd pedig a jelenlegi kutatásban külön nem részletezett környezetterhelés magas foka.

A kutatásból világosan kiderült, hogy Magyarország fővárosának és annak központi repülöterének tömegközlekedéssel történő megközelítését a válaszadók túlnyomó többsége a hosszú utazási idővel, illetve az alacsony kényelmi szinttel párosítja. Külön érdekesség, hogy bár kereslet az lenne rá, sokan a vasútra jelenlegi állapotában egyáltalán nem tekintenek lehetőségként a Budapest Liszt Ferenc Nemzetközi Repülőtér eléréséhez, amelyet orvosolni egy, a repülőtér termináljait közvetlenül elérő kötöttpályás gyorsvasút kiépítésével mindenképp érdemes lenne. Az autómegosztó szolgáltatások területén teljesen más fogyasztói problémák jelentkeztek, amelyek főleg a használatra, illetve a kezdeti regisztrációs nehézségekre $(50 \%)$ vonatkoznak, miközben kényelmi szempontból ez a kategória kapta a legjobb értékelést. A taxik esetében elsősorban a magas költségekkel kapcsolatban jelentkeztek negatív fogyasztói visszajelzések. 


\section{Következtetések}

A feltáró kutatásban az irodalmi áttekintés mellett netnográfiás alapokra építkező kutatással vizsgáltuk elsősorban az Y és a $\mathrm{Z}$ generációs utazók fogyasztói magatartását a Budapest Liszt Ferenc Nemzetközi Repülötér szárazföldi megközelíthetősége kapcsán. A repülőtér és a városközpont közlekedési kapcsolataival foglalkozó korábbi kutatások (MARK KIEFER CONSULTING 2019, MEYER et al. 2019, PEEREBOOM 2019) eredményei jelen kutatásunkban is részben megerősítésre kerültek. Látható, hogy a különböző közlekedési eszközök kapcsán eltérő véleményekkel és prioritásokkal rendelkeznek az utazók, ezek mentén pedig a kutatásunkban fontossági sorrendben az utazásra fordítandó idö, majd a költség, a kényelem és a rugalmasság tényezői jelentek meg. A közösségi közlekedés szempontjából különösen fontos kiemelni, hogy a kutatásunk eredményei Budapest esetében a hagyományos közlekedési formák egyelöre még egyértelmủ dominanciáját mutatják, amit a kvantitatív kutatásunk is alátámasztott.

Azonban kiindulva a MARK KIEFER CONSULTING (2019) kutatási eredményeiből, ahol a ridesharing szolgáltatók (Ride App/TNC) piaci részesedése pár év alatt a nulláról 29,5\%-ra nött, miközben a taxihasználat 18,6\%-ról 3,9-\%-ra esett vissza joggal feltételezhetjük azt, ha a fogyasztók rövid idő alatt képesek voltak az USA-ban ekkora mértékben megváltoztatni közlekedési szokásaikat, akkor ez a magyar fogyasztókkal is egyaránt megtörténhet. Az innovációkra való nyitottságot a jelen kutatásunk szintén bizonyította, a különböző autómegosztó szolgáltatások rövid idő alatt megugró népszerüsége is erre enged következtetni, tehát az, hogy a fent említett folyamat hazánkban a kutatás eredményei alapján még kevésbé indult meg, annak alapvetően nem a magyar utazók innovációk iránti érdeklödésének hiánya az oka.

A feltáró kutatásunkból láthatóvá vált, hogy a válaszadók jelentős része jelentősebb fenntartások nélkül nyitott az innovatív közlekedési megoldásokra, ahol legfőbb befolyásoló tényezőkként az utazási idő hosszúsága és a kényelem minősége voltak a meghatározóak. A megtett útra vetített költség, továbbá a használat általi rugalmasság kevésbé volt meghatározó tényező, miközben a kutatás eredménye egyértelműen rámutatott, hogy egy fogyasztó-centrikusabb látásmódra szükséges nagyobb figyelmet szentelni Budapest közlekedésében a repülőtér és a városközpont között, ami elsősorban nem az egyes közlekedési eszközök egyeduralmával, hanem valamennyi eszköz harmonizációjával érhető el leginkább.

A feltáró kutatás korlátai közé tartozik, hogy az kifejezetten az Y és a $\mathrm{Z}$ generáció igényeire fókuszált, ez azonban akár további kutatásoknak és gyakorlati megvalósítások tervezésének is alapját adhatja. A későbbi kutatásokban érdemes lehet további generációkkal, vagy a fenntarthatóság kérdéseivel kapcsolatos adatokat gyüjteni, illetve érdemes lehet fỏvárosokat összehasonlítani és a fogyasztók különbözö, akár nemzetiségek szerinti igényeit külön aspektusokból vizsgálni.

\section{A kutatás eredményeinek korlátai}

A kutatás eredményei elsősorban a 18-40 éves korosztályra korlátozódnak, ezért a megállapításaink elsősorban csak az Y és a Z generációk attitüdjeivel kapcsolatosak. A COVID-19 koronavírusjárvány utazási szokásokra gyakorolt hatása miatt, illetve a további generációk szintén jelentős keresletéből adódóan a repülőterek és a várostérségek közötti közlekedési kapcsolatok kereslete mindenképp további vizsgálatokat igényel. 


\section{Irodalomjegyzék}

ALBERT, G. - SZÜCS, H. (2018): Vonattal Ferihegyre? A repülőtér vasúti megközelítési lehetőségeinek gazdaságossági összevetése. Közlekedéstudományi Szemle 68(6): pp. 15-16. DOI: 10.24228/KTSZ.2018.6.2

BAKONYI, Z. - GYURITY, E. - HORVÁTH, Á. (2019): GreenGo's new strategy in the carsharing market of Budapest: How can a start-up defend its market against the largest company in the country? Emerald Emerging Markets Case Studies 9(1): pp. 1-23. DOI: 10.1108/EEMCS05-2018-0070

BERDE, É. (2018): Uber és taxi egymás mellett - új piaci modellek hagyományos árdiszkriminációval. Közgazdasági Szemle 65: pp. 650-666. DOI: 10.18414/KSZ.2018.6.650

BÉIRÃÖ, G. - CABRAL, J. A. S. (2007): Understanding attitudes towards public transport and private car: A qualitative study. Transport Policy 14(6): pp. 478-489. DOI: 10.1016/j.tranpol.2007.04.009

BOHL, P. - DUSEK, T. - KOPPÁNY, K. - LUKOVICS, M. - POREISZ, V. (2017): A Budapest Liszt Ferenc Nemzetközi Repülötér direkt helyi gazdasági hatása = Direct local economic impact of Budapest Liszt Ferenc International Airport. Területi Statisztika 57(1): pp. 76-93. DOI: 10.15196/TS570104

BOTHNER, A. - KRAMER, L. S. - SPIRO, M. (2013): How Airports Measure Customer Service Performance. Transportation Research Board 48: pp. 27

ERDÖSI, F. (1999): Légi közlekedés és területi fejlődés. Tér és Társadalom 13(4): pp. 45-76. DOI: 10.17649/TET.13.4.543

ERDÖSI, F. (2002): Gondolatok a közlekedés szerepéről a régiók/városok versenyképességének alakulásában. Tér és Társadalom 16(1): pp. 135-159. DOI: 10.17649/TET.16.1.840

GEBHARDT, L. - KRAJZEWICZ, D. - OOSTENDORP, R. - GOLETZ, M. - GREGER, K. KLÖTZKÉ, M. - WAGNER, P. - HEINRICHS, D. (2016): Intermodal urban mobility: users, uses, and use cases. Transportation Research Procedia 14: pp. 1183-1192. DOI: 10.1016/j.trpro.2016.05.189

GYÜRÜS, M. - PRÁCSER, A. - CSISZÁR, CS. (2008): Telematikai alapokon müködö carpooling rendszer. Budapesti Müszaki és Gazdaságtudományi Egyetem Közlekedésüzemi Tanszék, Budapest.

HORVÁTH, D - MITEV A. (2015): Alternatív Kvalitatív Kutatási Kézikönyv. Alinea Kiadó, Budapest.

İMRÉ, S. - ÇÉLÉBI, D. (2017): Measuring Comfort in Public Transport: A case study for İstanbul. Transportation Research Procedia 25: pp. 2441-2449. DOI: 10.1016/j.trpro.2017.05.261

JÁSZBERÉNYI, M. - MUNKÁCSY, A. (2018): Közlekedés, mobilitás, turizmus. Akadémiai Kiadó, Budapest.

KASARDA, J. D. (2000): Aerotropolis: Airport-Driven Urban Development. In: ULI on the Future: Cities in the 21st Century. pp. 32-41.

KASARDA, J. D. (2008): Shopping in the Airport City and Aerotropolis, New Retail Destinations in the Aviation Century. Research Review 15(2): pp. 50.

LEIPER, N. (1979): The Framework of Tourism. Towards a Definition of Tourism, Tourist and the Tourism Industry. Annals of Tourism Research 6(4): pp. 390-407. DOI: 10.1016/01607383(79)90003-3

LE-KLÄHN, D. T. - GERIKE, R. - HALL, C. M. (2014): Visitor Users vs. Non-users of Public Transport: The Case of Munich, Germany. Journal of Destination Marketing \& Management 3(3): pp. 152-161. DOI: 10.1016/j.jdmm.2013.12.005

MICHALKÓ, G. (2001): Turizmus és területfejlesztés. In: BELUSZKY, P. - KOVÁCS, Z. (szerk.): A terület és településfejlesztés kézikönyve. CEBA Kiadó, Budapest. pp. 113 - 120.

MICHALKÓ, G. (2008): A turisztikai tér társadalomföldrajzi értelmezésének új dimenziói. Magyar Tudományos Akadémia Földrajztudományi Kutatóintézet, Budapest. 
MICHALKÓ, G. - KISS, K. - KOVÁCS, B. (2009): Boldogító utazás: A turizmus hatása a magyar lakosság szubjektív életminőségére. Tér és Társadalom 23(1): pp. 1-17. DOI: 10.17649/TET.23.1.1213

MISKOLCZI, M. - JÁSZBERÉNYI, M. - TÓTH, D. (2021): Technology-Enhanced Airport Services-Attractiveness from the Travelers' Perspective. Sustainability. 13. 705. DOI: 10.3390/su13020705

PEEREBOOM, D. (2019): The prospect of carsharing. Barriers and solutions from a transition theory perspective in the city of Groningen. Rijksuniversiteit Groningen, Groningen.

PRENSKY, M. (2001): Digital Natives, Digital Immigrants. On the Horizon 9(5): pp. 1-6. DOI: 10.1108/10748120110424816

PUCZKÓ, L. - RÁTZ, T. (1998): A turizmus hatásai. Aula Kiadó - Kodolányi János Főiskola.

REDMAN, L. - FRIMAN, M. - GÄRLING, T. - HARTIG, T. (2013): Quality attributes of public transport that attract car users: A research review. Transport Policy 25: pp. 119-127. DOI: 10.1016/j.tranpol.2012.11.005

TÖRÖCSIK, M. (2009): Generációs Marketing. In: Bugár, Gy. - Farkas, F. (szerk.): Elkötelezettség és Sokoldalúság. Tanulmánykötet Barakonyi Károly Tiszteletére. Pécsi Tudományegyetem Közgazdaságtudományi Kar, Pécs. pp. 221-228.

TÖRÖCSIK, M. (2011): Fogyasztói magatartás - Insight, trendek, vásárlók. Akadémiai Kiadó, Budapest.

\section{Egyéb források}

MARK KIEFER CONSULTING (2019): 2019 Logan International Airport Air Passenger GroundAccess Survey.

https://www.massport.com/media/3403/2019-air-passenger-survey-final-report-082319.pdf

Letöltés: 2020. november 25.

MEYER, M. D. - MOSBAH, S. M. - WOLINETZ, L. D. (2019): Integrating Airport Ground Access and Metropolitan Surface Transportation Planning Efforts.

http://onlinepubs.trb.org/onlinepubs/acrp/acrp_rpt_216Contractor.pdf

Letöltés: 2020. november 25.

SOÓKI-TÓTH, G. (2018): Jövőtervezés a Budapest, Liszt Ferenc Repülőtér térségében. https://www.budcluster.eu/wp-content/uploads/2018/02/Jovotervezes_tanulmany_2018.pdf Letöltés: 2020. november 25.

World Tourism Organization (2019): International Tourism Highlights, 2019. UNWTO, Madrid. https://www.e-unwto.org/doi/epdf/10.18111/9789284421152

Letöltés. 2020. november 25.

World Tourism Organization (2021): International Tourism Highlights, 2020. UNWTO, Madrid. https://www.e-unwto.org/doi/epdf/10.18111/9789284422456

Letöltés. 2021. május 26. 